\title{
Autologous Stem Cell Therapy for Cerebral Palsy
}

\author{
Sagar Jawale, Vijay Bhaskar, Veeresh Nandikolmath, Shreedhar Patil \\ Jawale Institute of Pediatric Surgery, Jalgaon, Maharashtra, India \\ Email: drsaga rjawale@gmail.com,drvijji@yahoo.com, veereshnandikolmath@gmail.com, rohitpathlab@gmail.com
}

How to cite this paper: Jawale, S., Bhaskar, V., Nandikolmath, V. and Patil, S. (2020) Autologous Stem Cell Therapy for Cerebral Palsy. Open Journal of Pediatrics, 10, 36-64. https://doi.org/10.4236/ojped.2020.101004

Received: November 5, 2019

Accepted: January 17, 2020

Published: January 20, 2020

Copyright $\odot 2020$ by author(s) and Scientific Research Publishing Inc. This work is licensed under the Creative Commons Attribution International License (CC BY 4.0).

http://creativecommons.org/licenses/by/4.0/

\begin{abstract}
Introduction: We describe treatment of Cerebral Palsy with adult stem cells derived from bone marrow and fat of the same patient. Adult stem cells are of two types, the mesenchymal and haemopoietic stem cells which have potential to duplicate, indefinitely produce 50 types of growth factors that repair and regenerate tissues in an epigenetic manner. Every organ has its own stem cells, for example kidney stem cells, liver stem cells, etc. When specialized cells in an organ get damaged, the local stem cells come forward and get differentiated into specialized cells and the tissue damage is replenished. But when the stock of this reserve of local stem cell is over, the organ starts failing. In autologous stem cell therapy, we harvest stem cells from other healthy organs like fat and bone marrow which have abundant stem cells and put them into the diseased organ. Adult stem cells differentiate into neurons in vitro when added with nerve growth factor which is present in every nerve tissue. Our stem cell research was done by following all the guidelines set at national and international level. In India the incidence of cerebral palsy is around 5/1000 live births. In cerebral Palsy the upper motor neuron is weak, hence the lower motor neuron becomes hyper active leading to spasticity. The treatment involves mainly physiotherapy and prognosis is poor. Physiotherapy is a palliation and does not repair damage in the brain. The conventional therapy has failed to give any satisfactory results in these children hence something new needs to be done. Materials and Methods: In last 2 years we did stem cell therapy for 21 cases of $\mathrm{CP}$ in our center with age of 9 months to 17 years. Out of 21 cases of CP, 7 (33.3\%) cases had quadriplegia, $6(28.57 \%)$ paraplegia and $1(4.76 \%)$ monoplegia, 2 (9\%) hypotonic, 5 (23.8\%) hemiplegia, 4 (19.04\%) with mental retardation and 3 (14.28) had features of ADHD and Autism. 18 patients had squint in the eyes, 8 patients had food regurgitation and drooling of saliva, 2 patients had audiovisual impairment, 3 patients had bronchial asthma and one patient had menstrual irregularity. 26 cases were put as control with age range of 9 months to 19 years. 9 (34.61\%) pa-
\end{abstract}


tients had quadriplegia, 8 (30.76\%) paraplegia and 3 (11.53) had monoplegia, 3 (11.53\%) hypotonic, 5 (19.23) with mental retardation and 6 (23.07) had features of ADHD and autism. 21 patients had squint in the eyes, 11 patients had food regurgitation and drooling of saliva, 4 patients had audiovisual impairment, 5 patients had bronchial asthma in the control group. 11 patients were subjected to adipose tissue derived stem cell therapy and 10 with bone marrow derived stem cell therapy. All patients were examined at 3 monthly intervals. Maximum follow up was 2.5 years and minimum of one year. Results: The results of bone marrow derived stem cells and adipose tissue derived stem cells were almost the same. Results took 3 months to appear and positive outcome came till one year since therapy. The spasticity was significantly reduced in 15 out of 18 patients in 6 months. Out of 18 patients who had squint, it was regressed completely in $12(66.66 \%)$ patients and partially in $3(16.66 \%)$ in 6 months' time. 8 patients had faulty deglutition and $75 \%$ of them had $90 \%$ regression of symptoms. This fact is also reported for the first time in medical literature. Out of 15 patients who had spasticity, 10 had $75 \%$ reduction and 5 had 50\% reduction in spasticity. In our series, $3(33.33 \%)$ paraplegic and quadriplegic patients out of 9 are walking without support and another 6 (66.66\%) are walking with support. 2 patients had improvement in hearing and improved vision according to parents. There was no mortality. Morbidity was negligible in the form of fever, skin rashes, irritability and vomiting, etc. The GMFCS score had an average improvement of $1.238 \pm 0.56$ points about 12 months after therapy in therapy group compared to the control group which had an average improvement of $0.685 \pm 0.236$ points. The GMFM 88 total percentage score had an average improvement of $20.38 \pm 3.09$ in therapy group compared to $5.568 \pm 0.846$ in control group. The modified Ashworth scale score had an average drop of $2.285 \pm 0.76$ points compared to $1.126 \pm 0.348$ points in control group with difference of 12 month. Compared to the therapy group, in the control group only 2 (9\%) patients out of $22 \mathrm{had}$ mild regression of spasticity in 6 months. Only 3 patients out of 21 had mild regression of squint in 6 months. 16 patients out of 22 had the spasticity worse than before. Only 1 (5.88\%) patient out of 11 the food regurgitation was less than before. Out of 17 paraplegic and quadriplegic patients in control group only one started walking with support and none without support. All 5 patients continued to have same course of asthma as before. Discussion: It took 3 months to see the results. Positive changes were seen up to one year after therapy. Every child had on an average $20 \%-25 \%$ improvement after therapy. Best results were obtained below five years of age and moderate between age of 5 - 10 year. After the age of 10 year the results were average to poor and of palliative interest. The control group had no patients with such dramatic recovery in 12 months follow up. It clearly proves that the results are due to the stem cell therapy. The use of omental fat as a source for stem cells, the use of adipose derived stem cells for treatment of $\mathrm{CP}$, the regression of squint and correction in fault in deglutition in a series of patients are the facts reported by us for the first time in the medical literature by us. More than 50 trophic factors and growth factors released by mesenchymal stem 
cells are known to regenerate and repair the damaged nervous tissue in both the brain and the spinal cord by regenerative, anti-inflammatory and trophic mechanisms. Stem cells repaired the upper motor neuron in CP that lead to regression of spasticity and squint and the correction of faulty deglutition. The freshly prepared and implanting stem cell is a superior option than using cord blood derived and cryopreserved stem cells. Stem cells were photoactivated before implanting. Studies have shown that stem cells when exposed to far infrared light leads to activation of CXCR4 and ERK and induction and expression of SDF- $1 \alpha$ and IGF-1 at the mRNA level, and down regulation of TNF- $\alpha$ and TGF- $\beta$. Conclusions: Since Stem cell therapy is safe and effective in the treatment of Cerebral Palsy. We have developed world's cheapest stem cell therapy for Cerebral Palsy. Our research creates a lot of hope for millions of patients worldwide.

\section{Keywords}

Stem Cell Therapy for Cerebral Palsy, Autologous Stem Cell Therapy for Cerebral Palsy, Stem Cell Treatment for CP

\section{Introduction}

We describe the treatment of Cerebral Palsy with adult stem cells derived from bone marrow and fat of the same patient. The adult stem cells are of 2 types, mesenchymal and haemopoietic stem cells which have a potential to duplicate indefinitely and differentiate into 22 types of cells. The doubling time is only 3 days in children. These cells typically divide for up to 6 months making them into millions of cells. These cells have an intact positive and negative feedback mechanism and healthy genome with control on cell division. Hence, they divide only till necessary without forming benign and malignant tumors. These cells produce more than 50 types of growth factors and cytokines which repair and let grow adult tissues by acting in an epigenetic manner. Mesenchymal stem cells have the ability to differentiate into tissues of all 3 lineages a phenomenon called plasticity [1].

Every organ has its reserve of stem cells, for example, brain has a store of stem cells called nerve stem cells, liver has liver stem cells, etc. These stem cells are not far different from each other and from stem cells from adipose tissue and bone marrow. They are a common raw material for tissue repair. Whenever a particular organ undergoes damage, stem cells in that area come forewards and get differentiated into specialized cells and the damage is replenished. But when the damage is extensive, the organ starts failing. By doing stem cell therapy we harvest stem cells from other healthy tissues as adipose tissue and bone marrow and put them into the diseased organ and these cells secrete cytokines and growth factors which repair and regenerate existing healthy tissue of that organ and the organ starts functioning once again. We do not claim that the fibrous and dead tissue in the organ can get repaired and functional. We also do not claim that the adult stem cells will differentiate into new neurons. In health stem cells from 
adipose tissue or bone marrow cannot migrate into diseased organs, hence it is necessary to transplant them.

Stem cell therapy in $\mathrm{CP}$ is new and a lot of work is to be done before it can be fully established. The evidence in stem cell therapy is largely obtained from animal studies done on rats which are the research model of CNS for humans. The animal needs to be killed for the study and entire CNS sent in liquid nitrogen within 15 minutes after death. Certainly, such studies cannot be done in humans for the ethical reasons.

\subsection{Guidelines for Stem Cell Research}

Institutional Ethics Committee (IEC) Jalgaon city Indian Medical Association (IMA) of Jalgaon permission taken. The permission was taken well before the beginning of the study on 15/01/2016. The study started on 23/03/2017. The Institutional Committee for Stem Cell Research (IC-SCR) established at Jalgaon city level for peer review of stem cell research. Two visiting stem cell experts attached to the center with M. Phil degree in regenerative medicine. Collaboration done with Thermo Fischer Scientific, the world's largest cell media company. Money raised from Rotary club, Lion's club, MLA fund and other NGOs and patients were not charged for the study. In short, our stem cell research in tune with the government of India's guidelines.

The Helsinki's declaration which is the international code of ethics for medical research is important for this research. It states that in the treatment of an individual patient, where proven interventions do not exist or other known interventions have been ineffective, the physician, after seeking expert advice, with informed consent from the patient or a legally authorized representative, may use an unproven intervention if in the physician's judgement it offers hope of saving life, re-establishing health or alleviating suffering. This intervention should subsequently be made the object of research, designed to evaluate its safety and efficacy. In all cases, new information must be recorded and, where appropriate, made publicly available. The above guidelines were followed us strictly in this study.

Stem cell laboratory was set in just USD 500 instead of USD 5000 in the market. The cost of autologous stem cell transplantation dropped to USD 1000 in our hospital compared to USD 5000 in other places in India and USD 50,000 in USA. The charges offered by our center are the lowest in the world.

\subsection{Stem Cell Therapy for Cerebral Palsy}

Cerebral Palsy (CP) is a disabling condition that affects a child's life and his/her family irreversibly. It is usually a non-progressive condition but improvement over time is rarely seen. The etiology is prenatal hypoxia, metabolic, genetic, infectious, traumatic or other causes. It is therefore a heterogeneous group that results in functional motor disability associated with different degrees of cognitive abnormalities. The consequence is a major burden on the patient and family socially and financially [2] [3]. Physiotherapy and occupational therapy are the 
treatments that can bring some improvement in this condition. Physiotherapy is a palliation and does not repair damage in the brain. Recently, botulinum toxin therapy is used particularly for muscle spasticity part of CP. The conservative treatment for $\mathrm{CP}$ aims at functional, social and nutritional supportive care and counseling. In India the incidence of cerebral palsy is around 5/1000 live births. In cerebral Palsy the upper motor neuron is weak, hence the lower motor neuron becomes hyperactive leading to spasticity. The conventional therapy has given only a limited result in these children hence something new needs to be done.

There are several classifications used for $\mathrm{CP}$ depending on different elements of the motor function. The Gross Motor Function Classification System (GMFCS) detailed below is adjusted to age and reflects the degree of independent activities and functions. The score of 1 is the best and score of 5 is the worst of the lot. Another way to describe and classify CP is by the number of affected limbs (e.g. hemiplegia, hemiparesis, quadriparesis, etc. [4] [5]. A third method is based on the presence or absence of spasticity, coordination, and the muscle tone. Spastic hypertonic, or non-spastic, pyramidal or non-pyramidal based on the patient coordination. This description usually reflects the site and degree of pathology. The non-spastic, pyramidal type can be further classified as ataxic or dyskinetic types [6] [7].

In addition to these types and descriptions there are cases with mixed manifestations involving several features described above in associations with other elements like Autism and attention deficit and hyperactivity disorder (ADHD). This variety reflects the extent and variability of the pathobiology involving different areas of the central nervous system and makes it very difficult to study a real homogeneous group of subjects [8] [9].

This debilitating disease seemed a logical target for stem cell therapy to repair the neurologic defects, stimulate the endogenous stem cells to repair and regenerate and reestablish the lost balance between the different neurotrophic factors [10] [11] [12] [13] [14]. The aim of this study is to find out, whether injecting bone marrow aspirate concentrate (BMAC) intrathecally and intravenously once would help improve cerebral palsy patient's motor and cognitive functions as assessed by standardized tools described above.

There are two types of adult stem cells which can be used in Cerebral Palsy, one is bone marrow derived (BMAC) and another is an adipose tissue derived (ADSCS) derived. Both have abundant mesenchymal stem cells (MSCs) and hemopoietic stem cells (HSCs)The adipose tissue is supposed to have $500-3000$ times more stem cells compared to bone marrow. We developed both the methods at our center as both have their merits and demerits. Children with hematological disorders and low $\mathrm{Hb}$ who are contraindications for use of bone marrow can be subjected to adipose tissue derived stem cells for therapy.

\section{Materials and Methods}

In last 2 years, we did stem cell therapy for 21 cases of $\mathrm{CP}$ in our center with age 
of 9 months to 17 years. (Table 1) Inclusion criteria: Diagnosed cases of any type of Cerebral Palsy, age above 9 months. Exclusion Criteria: Presence of acute infections such as Human immunodeficiency virus/Hepatitis B Virus/Hepatitis C Virus, malignancies, bleeding tendencies, pneumonia, renal failure, severe liver dysfunction, severe anemia $[$ Hemoglobin $<8$ ], any bone marrow disorder, space occupying lesion in brain, other acute medical conditions such as respiratory infection and pyrexia.

Out of 21 cases of CP, 7 (33.3\%) cases had quadriplegia, 6 (28.57\%) paraplegia and 1 (4.76\%) monoplegia, 2 (9\%) hypotonic, 5 (23.8\%) had hemiplegia, 4 (19.04\%) with mental retardation and 3 (14.28) had features of ADHD and Autism. 18 patients had squint in the eyes, 8 patients had food regurgitation and drooling of saliva, 2 patients had audiovisual impairment, 3 patients had bronchial asthma and one patient had menstrual irregularity (Table 1). 26 cases were put as control with age range of 9 months to 19 years. 9 (34.61\%) patients had quadriplegia, 8 (30.76\%) paraplegia and 3 (11.53) were monoplegia, $3(11.53 \%)$ hypotonic 5 (19.23) with mental retardation and 6 (23.07) had features of ADHD and autism. 21 patients had squint in the eyes, 11 patients had food regurgitation and drooling of saliva, 4 patients had audiovisual impairment, 5 patients had bronchial asthma in the control group. 11 patients were subjected to adipose tissue derived stem cell therapy and 10 with bone marrow derived stem cell therapy. All patients were examined at 3 monthly intervals. Maximum follow up was 2.5 years and minimum of one year. The guardian(s) signed an informed consent form after full explanation of the procedure and the safety issues involved.

\subsection{Assessment Tool}

Our goal for the assessment was to perform it at three monthly intervals as much as possible. There was, however, a problem in many cases due to the children status and a number of missed visits that we tried to make up for as best suitable for the child and family. In some cases, the patients travelled from different places from India and we had to rely on the local neurologists and parent reports over the phone.

The Gross Motor Function Classification system (GMFCS) was used before and after therapy as a classification tool. GMFCS is a classification and is not an outcome measure. The Gross Motor Function Measure (GMFM) is an assessment tool designed and evaluated to measure changes in gross motor function over time or with intervention in children with cerebral palsy. GMFM-88 score was used for motor assessment of patients before and after therapy. The Modified Ashworth Scale (MAS) measures resistance during passive soft-tissue stretching and it was used to assess spasticity before and after therapy.

All patients were scanned before the therapy but the imaging findings were considered only as a guideline as in the therapy group and control group, we could not find a correlation between CT scan and MRI scan findings and patient's clinical condition. The assessment of the cognitive functions was done in 
a subjective manner with reliance mainly on the vocabulary used, understanding of spoken sentences in simple and complex formats. The assessment was done with the care taker and primary care physician when possible.

\subsection{Procedure for Separation of Stem Cells from Bone Marrow [15]}

On the day of the procedure, the bone marrow was collected under strict sterile conditions in the operating room with lamellar air flow under general anesthesia. About five ML per kg of marrow was collected from the anterior or posterior iliac crests depending on the patient posture and contractures. Six to eight puncture sites were used to aspirate the bone marrow. The marrow was aspirated using a $50 \mathrm{ml}$ syringe with heparin sodium as anticoagulants in a 10\% solution. The collected bone marrow e.g. $25 \mathrm{ml}$ is diluted with equal quantity of Dulbecco's Phosphate Buffered Saline with 2\% Fetal Bovine Serum (PBS + 2\% FBS). This solution is isotonic that avoids damage to stem cells by maintaining proper hydration and $\mathrm{PH}$ and has nutrients to keep stem cells alive for some time till they are given back into the body. The diluted bone marrow is poured over equal quantity of density gradient such as Lymph prep or Histopaque with density of $1.077 \mathrm{~g} / \mathrm{mL}$ into disposable centrifuge tubes of $50 \mathrm{ml}$ capacity. The tubes are centrifuged at $800 \times \mathrm{g}$ for 20 minutes at room temperature $\left(15^{\circ} \mathrm{C}\right.$ $25^{\circ} \mathrm{C}$ ) with brake off.

\subsection{Separation Principle [15]}

Differences in cell density are exploited to separate granulocytes and erythrocytes from MNCs. Granulocytes and erythrocytes have a higher density at the osmotic pressure of Density gradient medium and sediment through the Density gradient medium layer during centrifugation. The polysaccharide in Density gradient medium enhances erythrocyte aggregation, thereby increasing erythrocyte sedimentation. MNCs, with lower densities, remain at the plasma and Density gradient medium interface (Photo 1 , Photo 2 ) The layers that appear in the test tube from below upwards are RBCs, density gradient medium, buffy coat containing MNCs with stem cells and plasma above it as shown the in photo. The MNCs are collected by a long spinal needle of No. 20 attached to $10 \mathrm{ml} s y-$ ringe. Generally, $100 \mathrm{ml}$ bone marrow generates $10 \mathrm{ml}$ concentrate in the form of the buffy coat. The cells are counted using the Neubauer chamber. The vitality of cells is measured by a dye called Tropan blue. The damaged cells take the dye as their cell wall is damaged and healthy cells do not uptake the dye. The viability usually falls in the range of $95 \%$ - $98 \%$. A drop from this suspension is sent for cytology for staining and making a slide for a permanent record. The cell count is usually.

\subsection{Separation Protocol for Adipose Derived Stem Cells (ADSC) [16] [17] [18]}

Since these children are malnourished a small umbilical incision taken and half the omentum (Photo 3) was excised to be used as a source for stem cells. It is 


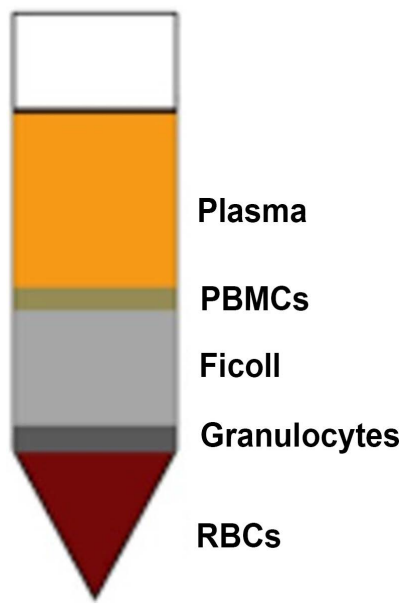

Photo 1. Diagrammatic Illustration of Buffy coat.

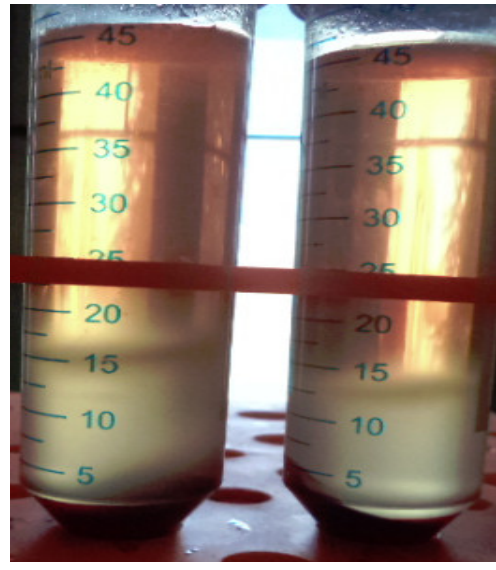

Photo 2. Actual buffy coat as a transverse disc.

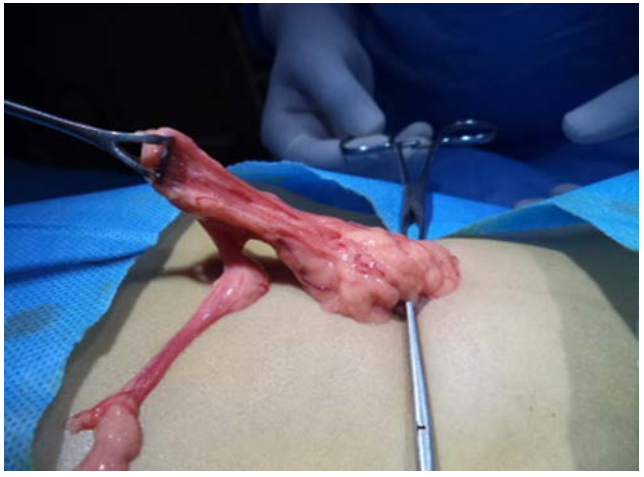

Photo 3. Omental fat being harvested for stem cells.

reported for the first time in medical literature. The fat was finely chopped and the lipoaspirate is put into 4 test tubes. It has 3 layers, an upper layer of oil due to the lysis of mature adipocytes, a middle layer of adipose tissue, and a bottom, 
liquid infranatant containing saline and contaminating cell types such as red blood cells (RBCs). The top oil layer may not be present in significant amounts. If present, it should be aspirated as oil contamination of the resulting ASC culture could affect the viability of the culture. The bottom infranatant should be removed prior to processing to minimize contamination of the ASC cultures with RBCs. This will leave the middle, adipose tissue layer, which will then be washed and enzymatically digested to liberate its cellular, stromal vascular fraction (SVF) (Photo 4). Washing the lipoaspirate: Open the lipoaspirate container in the tissue culture hood and carefully decant the lipoaspirate into a sterile 4 sterile test tubes of $50 \mathrm{ml}$. Allow the lipoaspirate layers to separate until the adipose tissue layer is well separated. Aspirate off the oil layer (if present) using a sterile, glass pipette and the bottom saline infranatant using a $10 \mathrm{ml}$ serological pipette. This will remove the greater majority of contaminating red blood cells and saline. Assess the volume of the resulting adipose tissue layer and add sterile $1 \times$ PBS at an equal volume. Stir the aspirate with the pipette used for aspiration in order to mix the lipoaspirate with the PBS. Allow the two layers to settle. As noted above, the $1 \times$ PBS may be supplemented with antibiotic/antimycotics. Aspirate the infranatant using a $10 \mathrm{ml}$ serological pipette. The adipose tissue fraction is washed till the adipose layer has a yellow/gold color. Aspirate the infranatant one last time, leaving the adipose tissue fraction in the glass beaker. To ensure adequate removal of the infranatant, allow the lipoaspirate layers to settle for $5 \mathrm{~min}$ after the last wash and before the final aspiration.

Enzymatic Digestion of the lipoaspirate [16] [17] [18]: Prepare sterile collagenase type 1 solution as outlined above in a filter unit. Prepare a volume equal to that of the adipose fraction and sterile filter. Following filtration of the collagenase solution, discard the upper filter unit, carefully pour the washed adipose fraction into the collagenase solution and tightly close the tubes. Place the collagenase/adipose mixture in a $37^{\circ} \mathrm{C}$ water bath and digest at $37^{\circ} \mathrm{C}$ for $30 \mathrm{~min}$. Gently swirl the collagenase/adipose mixture every $5-10 \mathrm{~min}$ and place back in the water bath. The adipose tissue layer should take on a "smoother" appearance as the digestion proceeds. Additional digestion times (i.e. up to $4 \mathrm{hr}$.) can be used if the adipose tissue layer still appears to have solid pieces of fat within it.

Isolation of ASCs: Place the digested collagenase/adipose mixture back into the biosafety cabinet. Be sure to sterilize the filter unit with $70 \%$ ethanol prior to placing back in the cabinet. Pipette $25 \mathrm{ml}$ aliquots of the infranatant containing the SVF into sterile $50 \mathrm{ml}$ centrifuge tubes. Add $25 \mathrm{ml}$ of CM to each tube. Allow the $\mathrm{CM}$ to inactivate the collagenase by incubating at room temperature in the cabinet for $5 \mathrm{~min}$. Centrifuge for $10 \mathrm{~min}$ at $1200 \times \mathrm{g}$ to collect the SVF (Photo 2) as a pellet. In the biosafety cabinet, aspirate the supernatant from each tube. Ensure the top oil layer and any floating adipocytes are aspirated with this supernatant. Combine the SVF pellets (Photo 4) into one centrifuge tube using $30 \mathrm{ml}$ $\mathrm{CM}$ and divide equally over two new $50 \mathrm{ml}$ centrifuge tubes. Centrifuge as in step 2.3.3. and aspirate the supernatants from the two SVF pellets. 


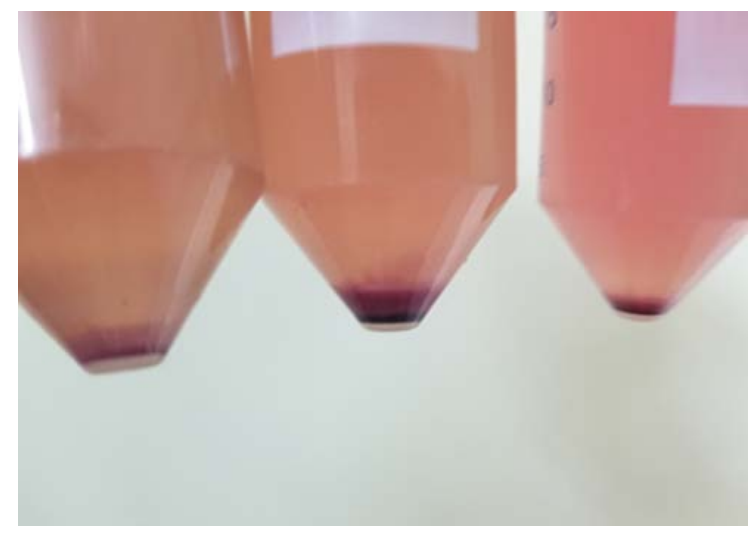

Photo 4. Stromal vascular fraction at the bottom of tubes.

Combine the two SVF pellets into one new centrifuge tube using $5-10 \mathrm{ml}$ CM. To filter out larger tissue particles, pipette the resuspended SVF pellet onto a $100 \mu \mathrm{m}$ mesh filter placed on top of a new $50 \mathrm{ml}$ centrifuge tube and allow to filter by gravity flow. Pipette aliquots of the resuspended (and filtered) SVF pellet containing the ASCs into PBS ready for injection.

\subsection{Activation of Stem Cells [19] [20]}

Stem cells need activation (Photo 5) before putting inside tissues. Otherwise they stay idle and will not replicate and repair tissues. In human body, stem cells are activated whenever there is trauma, injury and bacterial and viral infections. The field of activating stem cells artificially is extremely new and challenging as results depend on it. Only two research papers are written on the subject. But since the Far Infra-Red light is found to be safe on human tissues, we think that it is safe to use on stem cells for activation. We are aware that a lot more clinical pre assessment and animal studies are necessary before we can understand it better. In our center we activate stem cells with Far Infrared Light of $950 \mathrm{~nm}$ wavelength 50 minutes before injecting into body. Studies show that such cells survive much better and duplicate much more than otherwise. Since these machines are yet not available in the market, we developed a machine (Photo 5) with 100-watt power Infrared LED of $950 \mathrm{~nm}$ wavelength with a heat sink and an air-cooling fan.

A methyl prednisolone drip is started in the dose of $20 \mathrm{mg} / \mathrm{kg}$ body weight IV in normal saline. The half quantity of stem cells is injected intrathecally slowly over 15 minutes with lumbar puncture done by an anesthetist at the L4 L5 level under sterile conditions and under general anesthesia in the operating room. The remaining half quantity of stem cells is given intravenously slowly over 4 - 6 hours.

\section{Results}

11 patients were subjected to adipose tissue derived stem cell therapy and 10 with bone marrow derived stem cell therapy. The results of bone marrow 


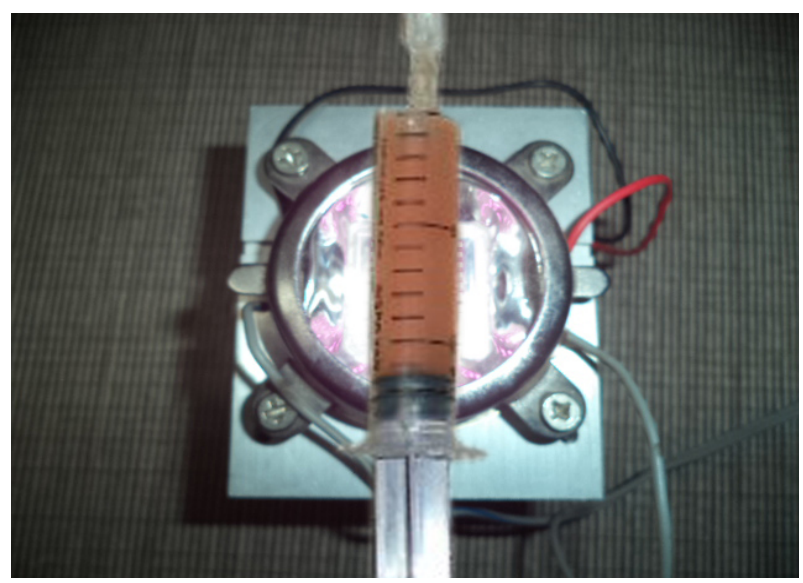

Photo 5. Photoactivation of stem cells by infrared light of $950 \mathrm{~nm}$.

derived stem cells and adipose tissue derived stem cells were almost the same. Patients in both groups were examined at 3 monthly intervals. Maximum follow up was 2 years and minimum of 6 months. Results took 3 months to appear and positive outcome came till one year since therapy. Few patients did not follow up physically and even for telephonic conversations. Hence their detailed history and examination could not be assessed. The spasticity was significantly reduced in 15 out of 18 patients (Photo 6, Photo 7) in 6 months. Out of 18 patients who had squint, it was regressed completely (Photo 8, Photo 9) in 12 (66.66\%) patients and partially in $3(16.66 \%)$ in 6 months' time (Table 1). It is reported for the first time in medical literature. 8 patients had faulty deglutition and $6(75 \%)$ of them had $90 \%$ regression of symptoms (Table 1). This fact is also reported for the first time in medical literature. Out of 15 patients who had spasticity, 10 had $75 \%$ reduction and 5 had $50 \%$ reduction in spasticity (Table 1 ). In our series, $3(33.33 \%)$ paraplegic and quadriplegic patients out of 9 are walking without support and another $6(66.66 \%)$ are walking with support. 2 patients had improvement in hearing and improved vision according to parents. There was no mortality. Morbidity was negligible in the form of fever, skin rashes, irritability and vomiting, etc. The GMFCS score had an average improvement of 1.1428 about 12 months after therapy (Table 1). Compared to the therapy group, in the control group only 2 (9\%) patients out of 22 had mild regression of spasticity in 6 months. Only 3 patients out of 21 had mild regression of squint in 6 months. 16 patients out of 22 had the spasticity worse than before. Only $1(5.88 \%)$ patient out of 11 the food regurgitation was less than before. Out of 17 paraplegic and quadriplegic patients in control group only one started walking with support and none without support. All 5 patients continued to have same course of asthma as before. The GMFCS score had an average improvement of $1.238 \pm 0.56$ points about 12 months after therapy in therapy group (Table 1 ) compared to the control group which had an average improvement of $0.685 \pm 0.236$ points. The GMFM 88 total percentage score had an average improvement of $20.38 \pm 3.09$ in therapy group compared to $5.568 \pm 0.846$ in control group. The modified 


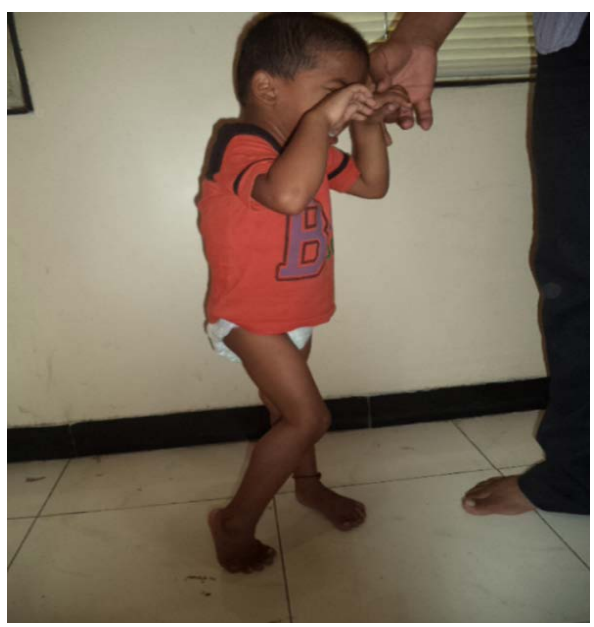

Photo 6. Spasticity with child standing on toes before therapy.

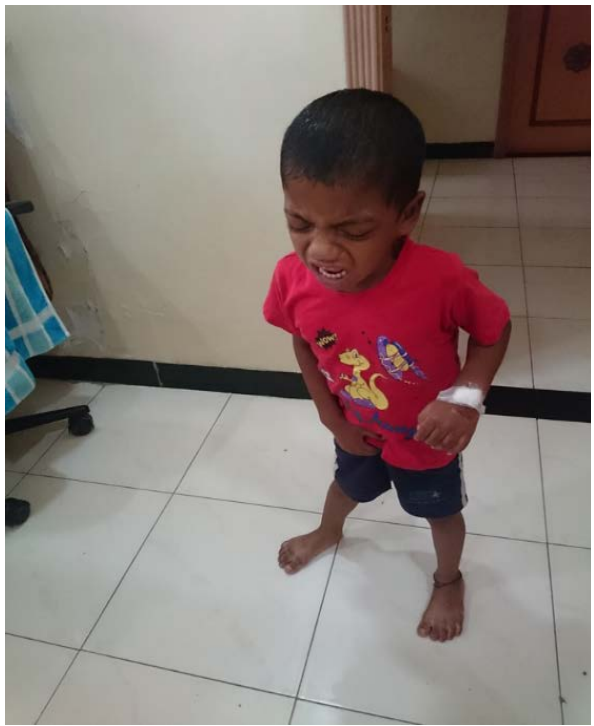

Photo 7. Child can put feet flat on ground after therapy.

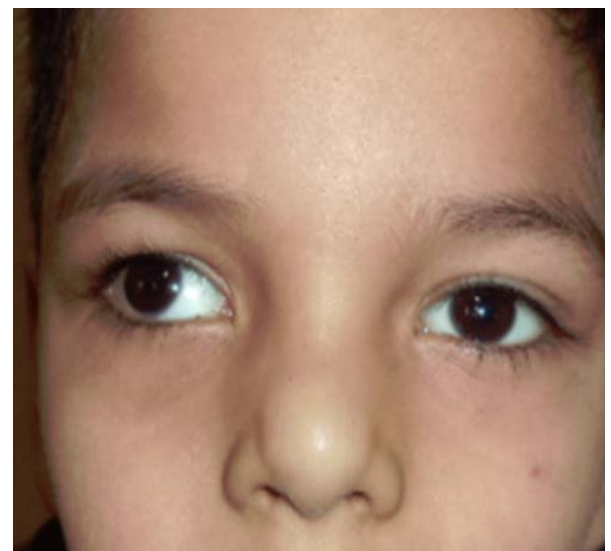

Photo 8. Squint before therapy. 


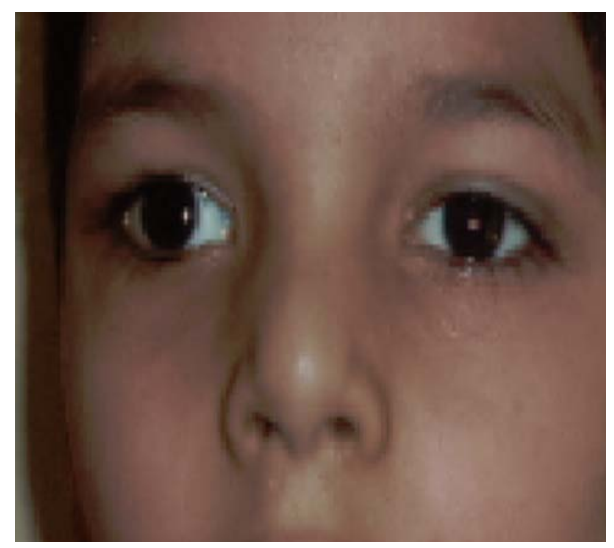

Photo 9. Squint regressed after therapy.

Ashworth scale score had an average drop of $2.285 \pm 0.76$ points compared to $1.126 \pm 0.348$ points in control group with difference of 12 months.

\section{Unusual Results of Stem Cell Therapy}

Three patients with CP had very bad bronchial asthma who had $90 \%$ regression in symptoms just 6 months after therapy (Table 1) and are free of asthma with 2 year follow up. One 15 years old girl had extremely irregular monthly cycle. In just 3 - 6 months it got regularized and remained so for 2 years till date. It means that we should have separate clinical trials for stem cell therapy in Bronchial Asthma and menstrual disturbances in woman.

\section{Discussion}

It took 3 months to see the results. Positive changes were seen up to one year after therapy. Every child had on an average $20 \%-25 \%$ improvement after therapy. Best results were obtained below five years of age and moderate between age of $5-10$ years (Table 1). After the age of 10 years the results were average to poor and of palliative interest. In 6 patients we advised the therapy to be repeated after one year and these children are likely to have further $20 \%-25 \%$ improvement over previous baseline. In the therapy group the results obtained were dramatic in a short period of 3 - 6 months. The control group had no patients with such dramatic recovery in 12 months follow up. It clearly proves that the results are due to the stem cell therapy. New results stopped coming after one year which proves that the regenerative cycle of stem cells is about one year. It also means that if one has to repeat the therapy, then the best time is after one year. Some centers call patients every monthly for therapy and inject cells monthly. When cells are dividing inside body for up to one year, it is unnecessary to implant them frequently which increases cost of therapy unnecessarily. Such a protocol appears to be more for earning money than to help patients.

The use of omental fat as a source for stem cells, the use of adipose derived stem cells for treatment of $\mathrm{CP}$, the regression of squint and correction in fault in deglutition in a series of patients are the facts reported by us for the first time in 
the medical literature by us. More than 50 trophic factors and growth factors released by mesenchymal stem cells are known to stimulate repair of damaged nervous tissue in both the brain and the spinal cord.

The Gross Motor Function Classification system (GMFCS) is an assessment tool [21] [22] based on the motor function initially developed in 1997 and then revised in 2007. It uses 5 levels describing the motor function limitations and taking into consideration age, the use of mobility aids and the quality of movement [21] [22]. Levels 1-5 of the GMFCS describe worse dysfunctions and less dependence during mobility as the level goes up. Levels 1 and 2 have almost independent mobility while level 3 can move with assistive devices and levels 4 and 5 are significantly limited and dependent on their helpers for minor movements. The environment and other personal factors have to be taken into consideration when making this assessment. In our series GMFCS score was calculated for all patients before therapy and 12 months afterwards in both groups. The GMFCS score had an average improvement of $1.238 \pm 0.56$ points about 12 months after therapy in therapy group compared to the control group which had an average improvement of $0.685 \pm 0.236$ points. This difference was found to be statistically highly significant $(P<0.0001)$.

The Gross Motor Function Measure (GMFM) is an assessment tool designed and evaluated to measure changes in gross motor function over time or with intervention in children with cerebral palsy (Table 1). It is of 2 types, GMFM-66 and GMFM-88. GMFM-88 is the original scoring method which has more detailed scores particularly for young children as in our series. Hence that was used as evaluation tool. It measures following faculties of a child, A-Lying \& Rolling, B-Sitting, C-Crawling \& Kneeling, D-Standing, E-walking running \& jumping.

Scores are calculated as follows. $0=$ does not initiate, $1=$ initiates, $2=$ partially completes, 3 = completes, NT = not tested. The total percentage score which is total of all A-E faculties was calculated before therapy and after 12 months of therapy in both groups as a percentage score. The difference of score was calculated in both groups and this difference is compared with each other in both groups. The GMFM 88 total percentage score had an average improvement of $20.38 \pm 3.09$ in therapy group compared to $5.568 \pm 0.846$ in control group. This difference was found to be statistically highly significant $(P<0.0001)$.

The Modified Ashworth Scale (MAS) measures resistance during passive soft-tissue stretching (Table 1). It is a quick and easy measure that can help assess the efficacy of treatment. It is measured as follows. Scoring $0=$ Normal tone, no increase in tone, $1=$ Slight increase in muscle tone, $1+=$ Slight increase in muscle tone, 2 = More marked increase in muscle tone through most of the muscles, but affected part(s) easily moved, 3 = Considerable increase in muscle tone, passive movement difficult, $4=$ Affected part(s) rigid in flexion or extension. The modified Ashworth scale score had an average drop of $2.285 \pm 0.76$ points compared to $1.126 \pm 0.348$ points in control group with difference of 12 months. This difference was found to be statistically highly significant $(P<$ $0.0001)$. 


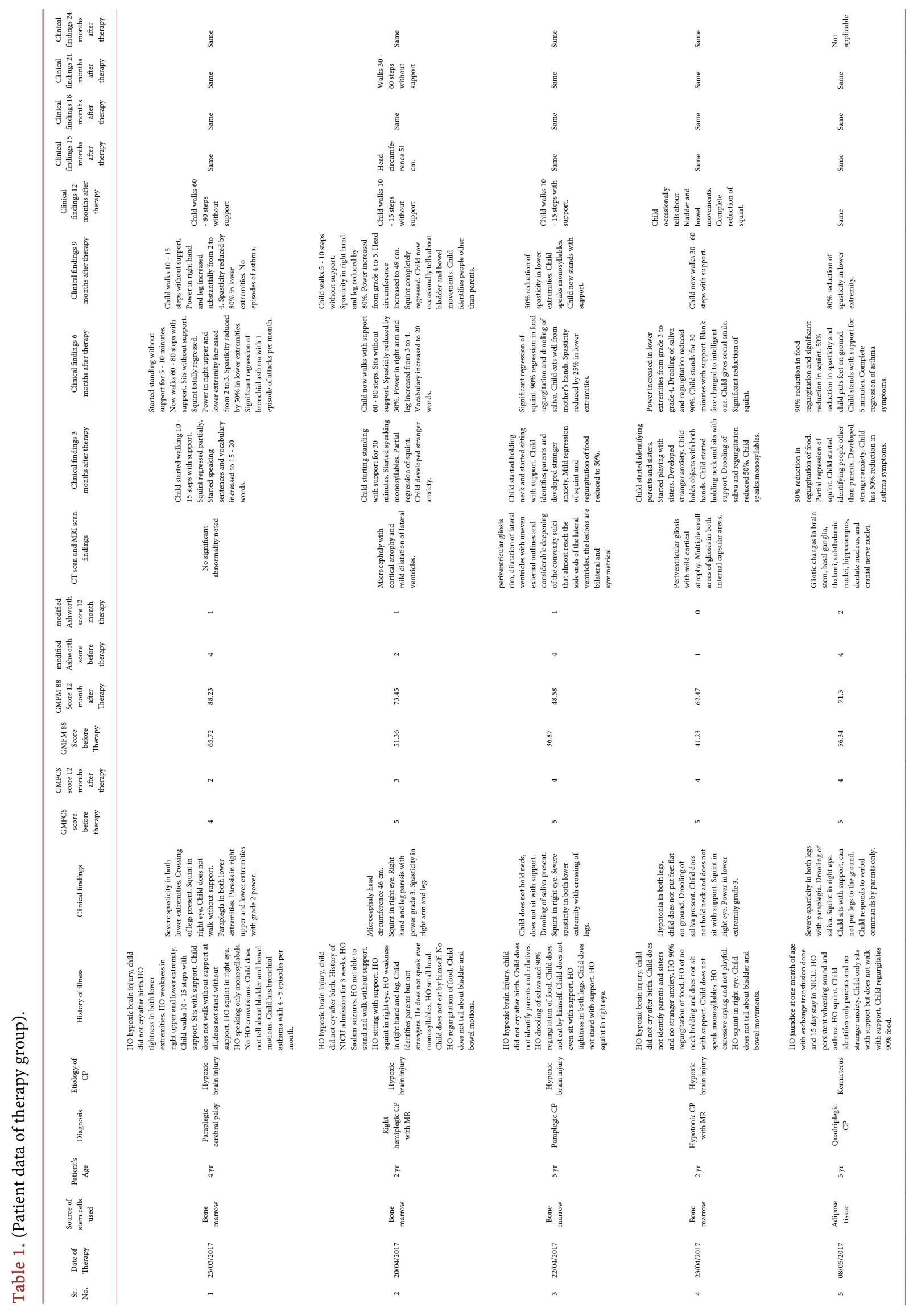




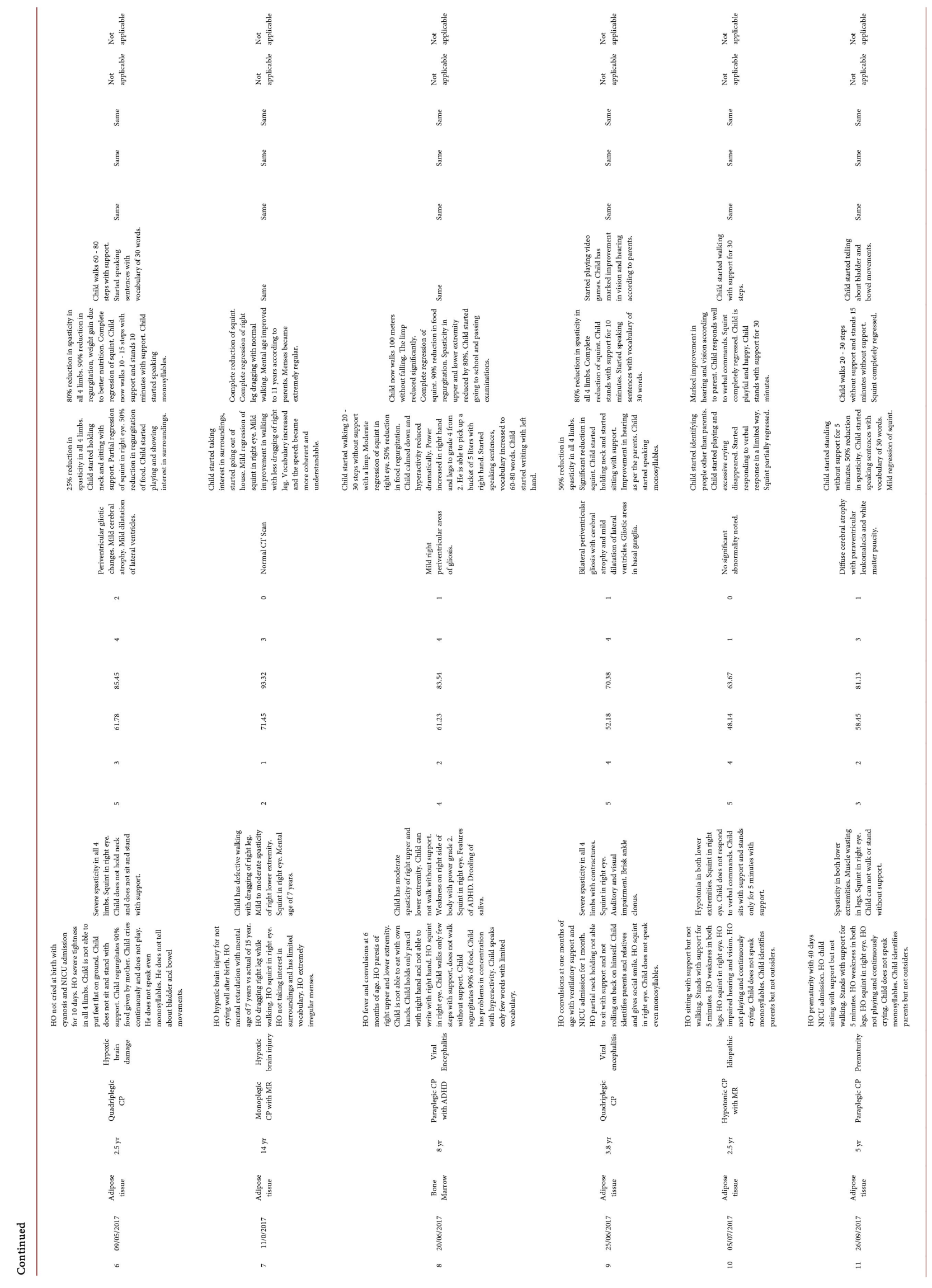




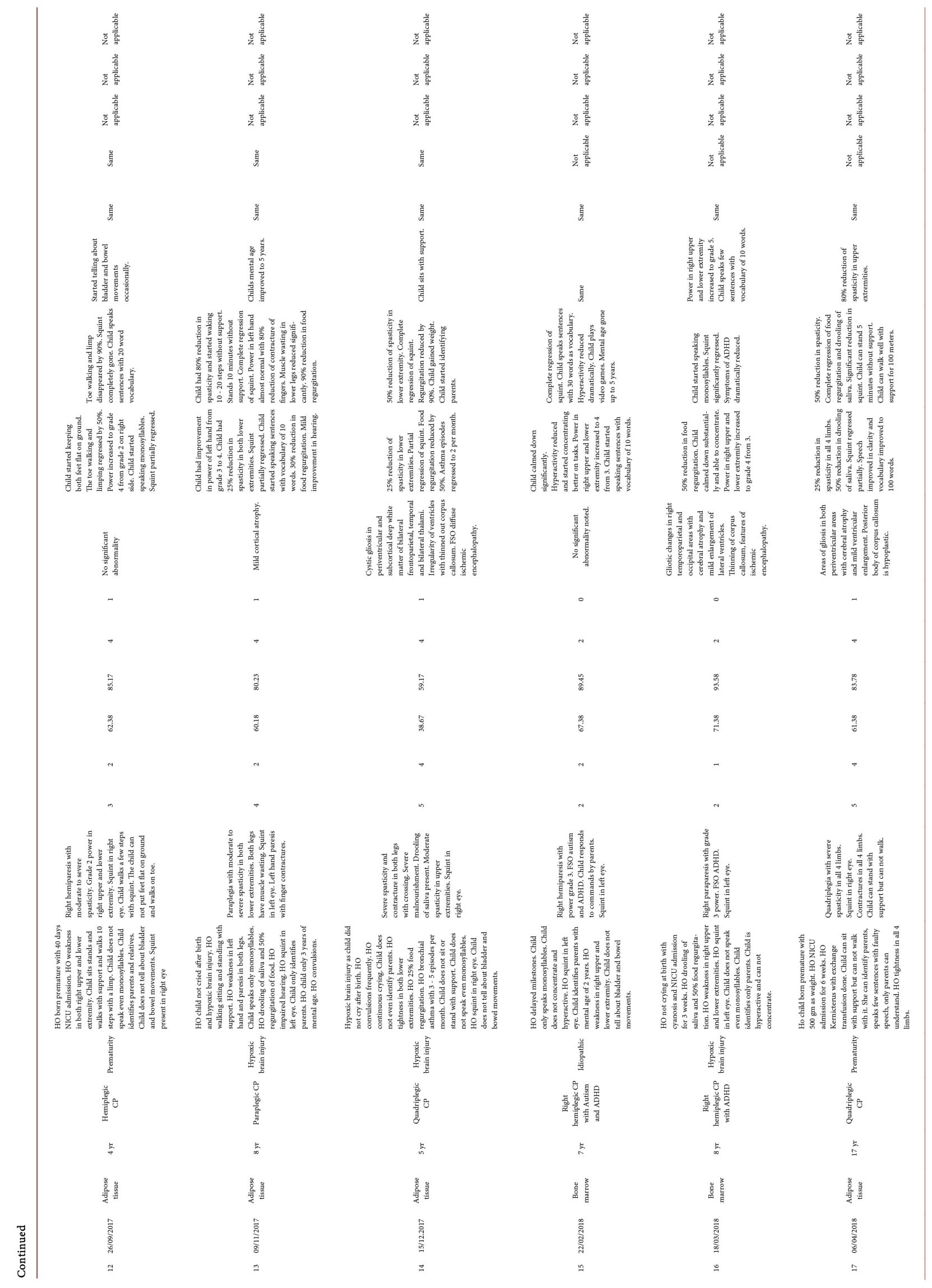




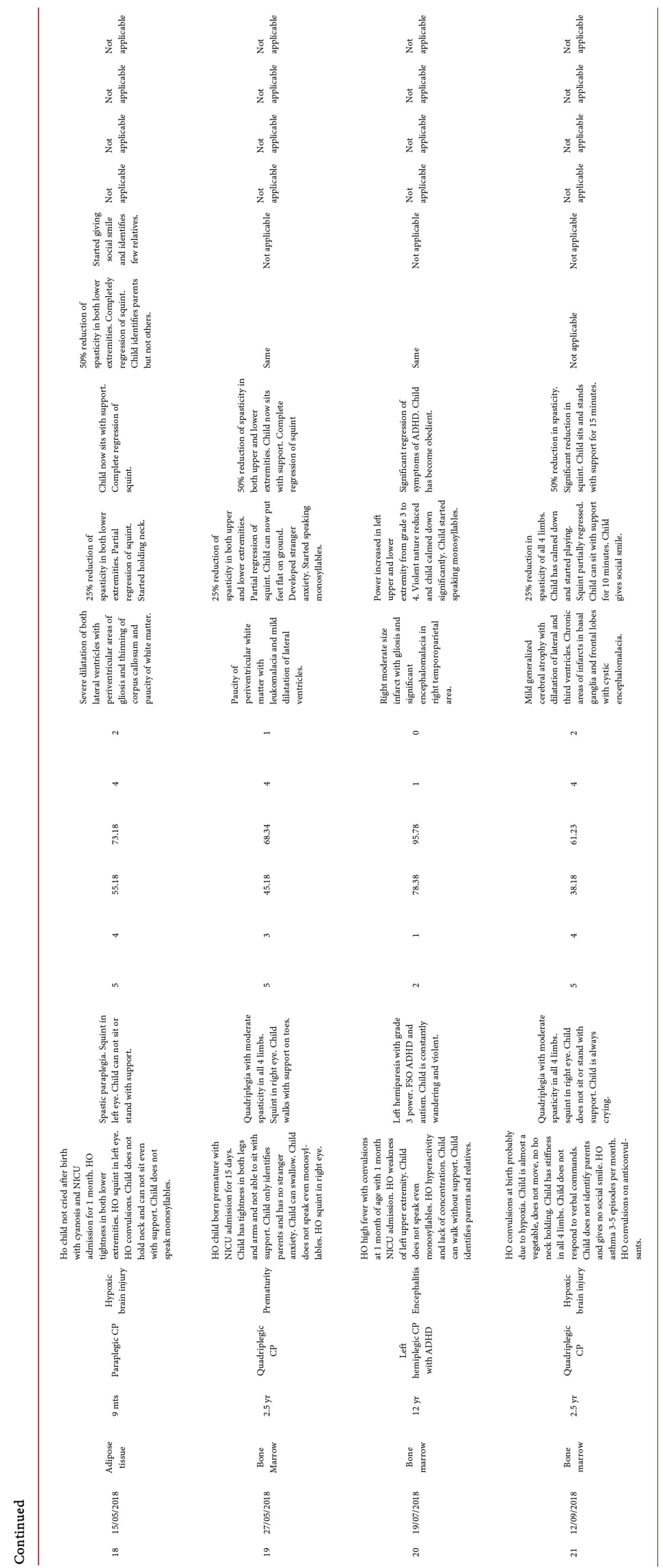


Many patients had significant damage on imaging but little clinical disability and many patients had normal to near normal imaging results but a significant clinical disability with delayed milestones. Since CT scan and MRI scans of 1.5 Tesla do not reveal lesions less than $5 \mathrm{~mm}$. Hence although millions of neurons have regenerated, it may not be seen on scans. Due to these limitations of scans a simple clinical assessment before and after therapy was used as assessment tool. All patients were scanned before the therapy but the imaging findings were considered only as a guideline as in the therapy group and control group, we could not find a correlation between CT scan and MRI scan findings and patient's clinical condition.

In our center we activate stem cells with Far Infrared Light of 950 NM wavelength 50 minutes before injecting into body. Following animal studies support our photoactivation of stem cells. The present study shows for the first time that the preconditioning effects of FIR on BMSCs include the activation of CXCR4 and ERK9 [22]. The study showed that FIR strongly induced the expression of SDF- $1 \alpha$ and IGF- 1 at the mRNA level, while down regulating TNF- $\alpha$ and TGF- $\beta$. AMD3100 and PD89059 treatment further confirmed that the preconditioning ability of FIR occurs via activation of CXCR4 and ERK. CXCR4 overexpression is a key part of enhancing the efficacy of stem cell homing and stem cell preconditioning through paracrine signaling mechanisms. CXCR4 overexpression in human adipose tissue-derived stem cells has been demonstrated to improve homing and engraftment in an animal limb ischemia model. In the case of acute kidney injury, the overexpression of CXCR4 has been shown to enhance the repair ability of BMSCs, increasing the homing of BMSCs and increasing the release of cytokines 22. In a case of skin injury repair, CXCR4 overexpression in BMSCs promoted wound healing in an SDF-1-expression-dependent manner.

The study done on rat bone marrow derived stem cells activated by Far Infra-Red light (FIR) highlight the novel insight that FIR preconditioning significantly promotes BMSC proliferation, migration, cell survival, and recovery against $\mathrm{H}_{2} \mathrm{O}_{2}$. In general, FIR radiation transfers energy to the cells and manifests a wide variety of biological effects, including improvement of ischemic lesions. Although the biological activities of FIR in the preconditioning of BMSCs by in vitro manipulation are not fully understood, the findings corroborate previous studies of wavelength in the red range for example, red $(630 \mathrm{~nm})$ and near infrared $(850 \mathrm{~nm})$ light-emitting diodes enhance the migration of MSCs derived from rat bone marrow. Other studies have demonstrated that a diode (Ga-As) laser of wavelength $804 \mathrm{~nm}$ promotes the proliferation of BMSCs and cardiac stem cells. Another study has suggested that postconditioning with FIR increases heme oxygenase-1 expression and protects against I/R injury in rat testes.

Another study that uses diode laser to photo activate stem cells. In the present study the effects of $635 \mathrm{~nm}$ diode laser on mouse MSC proliferation (20) and investigated the underlying cellular and molecular mechanisms, focusing the attention on the effects of laser irradiation on Notch-1 signal activation and membrane ion channel modulation. It was found that MSC proliferation was signifi- 
cantly enhanced after laser irradiation, as judged by time lapse video microscopy and Edu incorporation. This phenomenon was associated with the up-regulation and activation of Notch-1 pathway, and with increased membrane conductance through voltage-gated $\mathrm{K}^{+}, \mathrm{BK}$ and $\mathrm{Kir}$, channels and $\mathrm{T}$ - and L-type $\mathrm{Ca}^{2+}$ channels. The study also showed that MSC proliferation was mainly dependent on Kir channel activity, on the basis that the cell growth and Notch-1 up-regulation were severely decreased by the pre-treatment with the channel inhibitor $\mathrm{Ba}^{2+}$ $(0.5 \mathrm{mM})$. Interestingly, the channel inhibition was also able to attenuate the stimulatory effects of diode laser on MSCs, thus providing novel evidence to expand our knowledge on the mechanisms of bio stimulation after LLLI. In conclusions, our findings suggest that diode laser may be a valid approach for the preconditioning of MSCs in vitro prior to cell transplantation.

The mechanisms by which stem cells treat cerebral palsy [23] are proposed to include a) regenerative mechanisms, replacement and/or repair of damaged brain cells brought about by engraftment and proliferation of transplanted cells, which may or may not include differentiation of transplanted cells into new microglia or astrocytes to promote reorganization; b) anti-inflammatory mechanisms, attenuation of the inflammatory immune response to brain injury, via a reduction in the release of excitotoxins, cytotoxins, and oxygen free radicals, which if used early enough might evoke a protective response that reduces the size and extent of the white matter injury; and c) trophic mechanisms, to promote cell survival via release of neurotrophic factors secreted from progenitor cells [23] to induce endogenous cell migration, proliferation, and differentiation and/or to promote angiogenesis and new blood vessel formation.

Some of these are neurotrophic factors [23] that promote neuronal growth, induce new blood vessel growth (hemopoietic stem cells), neurogenesis and astroglia activation, encourage synaptic connection and axonal remyelination, decrease programed cell death, and regulate microglial activation. We do not claim that the fibrous tissue developed in the brain called gliosis will regenerate and blossom into healthy tissue. Our claim is that the healthy tissue is repaired and regenerated.

Growth factors like G-CSF, Stem Cell Factor (SCF), the fibroblast growth factor (FGF) and others may reduce the volume of ischemia and increase migration and proliferation of the stem cells. The bone marrow endothelial precursors may also improve angiogenesis up to 2 months post insult. There is evidence that the growth factors like the ones released from the stem cells may help improve brain regeneration [24] [25] [26]. There are various strategies for environmental enrichment utilizing stem cells to provide de novo synthesis and delivery of neuroprotective growth factors at the site of disease. Growth factors such as glial-derived neurotrophic factor (GDNF), brain-derived neurotrophic factor (BDNF), insulin-like growth factor-I (IGF-I), and vascular endothelial growth factor (VEGF) are protective in neurodegenerative disease models and provide in situ environmental enrichment at the main locus of disease. [27] [28] [29] [30] Other factors affecting the potential efficacy of cellular therapies include 
integration of grafted neurons, migration of engrafted cells, and the distances that axons need to extend to reach their targets. Bone marrow-derived cells developing neuronal and vascular phenotype sand aiding in repair of injured brain have been reported [27].

The stem cells can regenerate neurons and other supportive cells. Transplanted bone marrow cells infiltrate the brain and may help regenerate new elements or combat the neurodegenerative process, fibrosis and oxidative insults. The result is potential repair of the damaged tissues [30]. Neuroprotection may involve release of several neurotrophic factors, that work through paracrine and/or-autocrine interactions [31].

There are several effective mechanisms of action involved in the stem cell induced repair of brain tissue such as regeneration of the neural cells, direct stimulation of the neurons, the endogenous stem cells as well as neovascularization and trophic paracrine mediators. There are only some animal data to illuminate the mechanisms of the stem cell actions in vivo and no significant post mortem data to further improve our understanding at this point in time [26] [32] [33].

Mesenchymal stem cells (MSCs) are multipotent and give rise to distinctly differentiated cells from all three germ layers. Neuronal differentiation of MSC has great potential for cellular therapy. We examined whether the cluster of mechanically made, not neuro-sphere, could be differentiated into neuron-like cells by growth factors, such as epidermal growth factor (EGF), hepatocyte growth factor (HGF), and vascular endothelial growth factor (VEGF).

Stem cells repaired the upper motor neuron in CP that lead to regression of spasticity and squint. Animal studies show that mesenchymal stem cell put into CSF can migrate into the brain and duplicate and survive. Stem cells when added with Nerve Growth Factor (NGF) in vitro get differentiated into neurons [34]. Stem cells put intrathecally reversed experimentally produced brain damage in animals. The act of deglutition is a complex one with multiple muscles and their cranial nerves and centers in the brain involved in it. The eye is controlled by muscles with nerve supply coming from the cranial nerves and the centers located deep inside brain. The correction of faulty deglutition and squint in our series proves that stem cells and or the growth factors and cytokines reached the deeper areas of the brain in the nuclei of cranial and repaired them.

Treatment of Cerebral Palsy with Stem Cells in a study of 17 Cases [34] had the efficacy of the stem cell therapy and pre and post injection follow-ups was available for 15 evaluable patients Eleven of the 15 had significant improvement (73\%). The improvement ranged from 1 to 3 levels on the GMFCS scoring system. The average improvement was 1.3 points with a range of 0 to 3 points of improvement with no patients showing regression. The improvement was most pronounced in the degree of spasticity in 6 patients (40\%) and in many cases it was the first feature noted to improve. Some families reported bowel and bladder control improvement along with the motility and independent activity. The cognitive function assessment also revealed significant improvement in 6 of the 15 patients (40\%). The assessment was performed with the help of the care givers 
and the patient's primary physicians. Even though not every patient improved, overall, the majority of patients showed significant improvements in situations that were hopeless. Some patient functional improvement was significant and they improved to a point of becoming somewhat independent (4 of 15, or 27\%).

In another study of autologous stem cell therapy in CP patients [35], gross motor function was markedly improved 3 months or 6 months after stem cell transplantation than at baseline. The post-transplantation GMFM-88 total score, each of its domains and the GMFM-66 percentile were all significantly higher $(p$-value $<0.001)$. Muscle spasticity also reduced significantly after transplantation ( $p$-value $<0.001)$. The therapy was equally effective regardless of sex, age and GMFCS level ( $p$-value $>0.05$ ).

A randomized, placebo-controlled trial of human umbilical cord blood mesenchymal stem cell infusion for children with Cerebral Palsy was done on 54 cases, 27 in therapy group and 27 in control group [36] who received only saline infusions. The changes in the total proportion of GMFM-88 and total scores of CFA in the h UCB-MSC infusion therapy group were significantly higher than that in control group at 3,6,12, 24 months posttreatment. Less diffuse slow waves were noticed after h UCB-MSC infusion in patients with slowing of EEG background rhythms at baseline. Based on the routine MRI exams, improvements in cerebral structures were rare after treatment. Serious adverse events were not observed during the whole study period. The results of the study indicated that h UCB-MSC infusion with basic rehabilitation was safe and effective in improving gross motor and comprehensive functions in children with $\mathrm{CP}$.

Sharma et al on mean follow-up of $15 \pm 1$ month post-stem cell administration, reported an improvement in $85 \%$ CP cases [37]. Out of which $75 \%$ reported improvement in muscle tone and $50 \%$ in speech among other symptoms. No significant adverse events were noted. There was significant improvement of the quality of life as well. Improvement in muscle tone (15/20) and speech $(10 / 20)$ as well as significant reduction in seizure frequency $(2 / 20)$ patients and dystonic movements, improved limb strength (11/20) patients were observed. On FIM scale, 3 of them showed improved scores.

In a case series of 40 patients, Human Embryonic Stem Cell Therapy was given in Cerebral Palsy Children with Cortical Visual Impairment of 40 visually impaired children [38]. The patients were mostly males (n-24) between the age group of 0 to 16 years. Eight patients had NFS "1" (were blind/had no perception of light); 16 had NFS "2" (perception of light); 10 had NFS " 3 " (could identify blurred images); 6 had NFS "4" (could see objects up to a distance of $25 \mathrm{~cm}$ from the eye); and no patients had NFS " 5 ". Of the 24 patients with an NFS of level 1 and level 2; 7 had squint; 3 had night blindness; 4 had nystagmus; and 4 had restricted eye movements. At the end of all treatment phases (331 treatment days), 39 patients showed an improvement in NFS by at least one level. A total of 27 patients regained their normal vision; 10 patients could see objects up to a distance of $25 \mathrm{~cm}$ from the eye; 2 patients could see blurred images; and 1 patient had perception of light. Of the 8 patients who had NFS 1, 3 patients transitioned 
to NFS 5, 3 patients transitioned to NFS 4; and one each to NFS 3 and NFS 1 at the end of all treatment phases. Of the 16 patients who had NFS 2 at the beginning of the study, 9 patients transitioned to NFS 5, 6 patients transitioned to NFS 4, and one patient to NFS 3 . All 10 patients who had NFS 3 at the beginning of the study transitioned to NFS 5 at the end of all treatment phases. Five of 6 patients who had NFS 4 transitioned to NFS 5 however; one patient showed no change at the end of treatment.

Following argument is why other centers do not get required results. Stem cell therapy requires harvesting $50-100 \mathrm{ML}$ of bone marrow in a small child which is skillful, sometimes $5 \mathrm{ml}$ also does not come out. If you do not harvest enough bone marrow you do not get results. It must be done in 5 - 10 minutes as cells hemolyze and buffy coat will not develop. Then there are no cells obtained for putting into the patient. Photoactivation of stem cells by infrared light is a recent innovation and not done by many therapists. Many therapists do not inject stem cells into CSF and only into blood. Studies have shown that only CSF implanted stem cells make it into the brain parenchyma [39] [40]. Stem cells are very delicate and have to be implanted immediately otherwise they start dying. Some centers have a lag period of 24 hours whereas we implant the cells within one hour of separation.

Autologous Stem cells were injected intravenously gave results [41] [42] [43] [44] but cells are large and do not cross blood brain barrier. The growth factors and cytokines produced by stem cells cross blood brain barrier as they are small molecules. To cross the obstacle of blood brain barrier, half the quantity of stem cells was given intrathecally. [42] [45] Animal studies in which stem cells were tagged by fluorescent antibodies and injected intravenously showed much higher concentration in brain parenchyma than the intravenous route.

There are other sources of stem cells described in medical literature for treatment in cerebral palsy. We would discuss them and compare with our method. The commonest source other than autologous is cord derived stem cells [34] [45] [46] [47] [48]. It can be fresh blood taken from recent delivery, stored for one month and stored for 25 years of the same or another patient. Since hemopoietic stem cells have $\mathrm{ABO}$ antigen, this blood has to be cross matched before giving to patient. Matching donors and limited availability because of it are disadvantages of this method. The cord blood has the same hemopoietic stem cells as in child's bone marrow, hence it is no way superior. The cord blood is generally $5-10 \mathrm{ml}$ whereas successful implantation requires $50-100 \mathrm{ml}$ bone marrow to get results. Blood stored for one month has reduced cell vitality and count. The above allogenic options have a risk of disease transmission like HIV, Hepatitis B, Hepatitis C, etc.

The cryopreserved blood of same patient or another patient appears to be an inferior option to us for following reasons. The cryopreserved blood when defrosted were found to have far less viable stem cells seen under the microscope [49]. A lot of stem cells had damaged cell walls when stained with Tropan Blue. On many occasions these cells failed to grow in culture putting a serious ques- 
tion mark on their viability. Dead stem cells have no role in regenerative medicine. American association of Pediatrics is totally against the Umbilical cord stem cell preservation particularly by private banks and recommend public banks for the purpose. According to us the only scientific stem cell therapy is stem cells freshly prepared and put back into the patient's body within $1-24$ hours. The above argument proves why our method of implanting patient's own stem cells is a scientific, legal and ethical option.

Limitations of this study are that enough stem cells do not penetrate the brain parenchyma when put in CSF and into the blood steam due to the blood brain barrier. Cells also do not survive more that few weeks into implanted organ. We need further research to find out solutions to these problems.

\section{Future Prospects of Stem Cell Therapy}

In our laboratory, one billion Stem cells were cultured to be given to the patient at monthly intervals without harvesting tissue again at record low cost of USD 100 instead of USD one million. Stem cells can be transdifferentiated to neurons in laboratory and infused in the CSF at only USD 200 per billion. Stem cells and or transdifferentiated neurons can be directly implanted in the brain where ever they are necessary gives dramatic results. It requires DCGI permission hence were produced, photographed and discarded instead of injecting into patients. Stem cells were transduced into neural stem cells and directly implanted into brain parenchyma in stroke patients in Harvard University. It gave dramatic results which were not obtained by implanting cells into CSF. We plan shortly to try it for Cerebral Palsy patients which would be for the first time in the medical literature. We should reserve such options for patients with severe damage and patients above 10 years of age.

\section{Conclusion}

Since stem cell therapy is safe and effective in the treatment of Cerebral Palsy. The therapy group has substantially superior results compared to the control group when compared objectively by objective criteria such as GMFCS classification score, GMFM-88 score and modified Ashworth scale score and the difference came to be statistically highly significant. We need a greater number of cases and a longer follow up. The therapy can be repeated multiple times with an affordable cost and is proving to be a much superior treatment option compared to the conventional therapy. We have developed world's cheapest stem cell therapy for Cerebral Palsy. Since our stem cell therapy and research are made possible at a district place and not in a tertiary health care center, it means that many doctors in India and other third world countries can perform it even in small towns, hence it creates a lot of hope for millions of patients worldwide.

\section{Conflicts of Interest}

The authors declare no conflicts of interest regarding the publication of this paper. 


\section{References}

[1] Bae, K.S., Park, J.B., Kim, H.S., Kim, D.S., Park, D.J. and Kang, S.J. (2011) Neuron-Like Differentiation of Bone Marrow-Derived Mesenchymal Stem Cells. Yonsei Medical Journal, 52, 401-412.

[2] Spencer, N.J., Blackburn, C.M. and Read, J.M. (2015) Disabling Chronic Conditions in Childhood and Socioeconomic Disadvantage: A Systematic Review and $\mathrm{Me}$ ta-Analyses of Observational Studies. BMJ Open, 5, e007062. https://doi.org/10.1136/bmjopen-2014-007062

[3] My Child at CerebralPalsy.org. (2015) http://cerebralpalsy.org/about-cerebral-palsy/costs

[4] Andersen, G.L., Irgens, L.M., Haagaas, I., Skranes, J.S., Meberg, A.E. and Vik, T. (2008) Cerebral Palsy in Norway: Prevalence, Subtypes and Severity. European Journal of Paediatric Neurology, 12, 4-13. https://doi.org/10.1016/j.ejpn.2007.05.001

[5] Cauraugh, J.H., Naik, S.K., Hsu, W.H., Coombes, S.A. and Holt, K.G. (2010) Children with Cerebral Palsy: A Systematic Review and Meta-Analysis on Gait and Electrical Stimulation. Clinical Rehabilitation, 24, 963-978. https://doi.org/10.1177/0269215510371431

[6] Bax, M., Goldstein, M., Rosenbaum, P., Leviton, A., Paneth, N., Dan, B., Jacobsson, B. and Damiano, D. (2005) Proposed Definition and Classification of Cerebral Palsy, April 2005. Developmental Medicine \& Child Neurology, 47, 571-576. https://doi.org/10.1017/S001216220500112X

[7] Driscoll, S.W. and Skinner, J. (2008) Musculoskeletal Complications of Neuromuscular Disease in Children. Physical Medicine and Rehabilitation Clinics of North America, 19, 163-194. https://doi.org/10.1016/j.pmr.2007.10.003

[8] Christensen, D., Van Naarden Braun, K., Doernberg, N.S., Maenner, M.J., Arneson, C.L., Durkin, M.S., Benedict, R.E., Kirby, R.S., Wingate, M.S., Fitzgerald, R. and Yeargin-Allsopp, M. (2013) Prevalence of Cerebral Palsy, Co-Occurring Autism Spectrum Disorders, and Motor Functioning-Autism and Developmental Disabilities Monitoring Network, USA, 2008. Developmental Medicine \& Child Neurology, 56, 59-65. https://doi.org/10.1111/dmcn.12268

[9] Shevell, M.I., Dagenais, L., Hall, N. and Repacq Consortium (2009) The Relationship of Cerebral Palsy Subtype and Functional Motor Impairment: A Population-Based Study. Developmental Medicine \& Child Neurology, 51, 872-877. https://doi.org/10.1111/j.1469-8749.2009.03269.x

[10] Nishio, Y., Koda, M., Kamada, T., Someya, Y., Kadota, R., Mannoji, C., Miyashita, T., Okada, S., Okawa, A., Moriya, H. and Yamazaki, M. (2007) Granulocyte Colony-Stimulating Factor Attenuates Neuronal Death and Promotes Functional Recovery after Spinal Cord Injury in Mice. Journal of Neuropathology \& Experimental Neurology, 66, 724-731. https://doi.org/10.1097/nen.0b013e3181257176

[11] Serefhanoglu, S., Goker, H., Buyukasik, Y., Turgut, M., Sayinalp, N., Haznedaroglu, I.C., Aksu, S., Akman, U. and Ozcebe, O.I. (2009) Changes in Vascular Endothelial Growth Factor, Angio-Poietins, and Tie-2 Levels with G-CSF Stimulation in Healthy Donors. Annals of Hematology, 88, 667-671.

https://doi.org/10.1007/s00277-008-0657-7

[12] Haynes, R.L., Xu, G., Folkerth, R.D., Trachtenberg, F.L., Volpe, J.J. and Kinney, H.C. (2011) Potential Neuronal Repair in Cerebral White Matter Injury in the Human Neonate. Pediatric Research, 69, 62-67.

https://doi.org/10.1203/PDR.0b013e3181ff3792 
[13] Fancy, S.P., Harrington, E.P., Yuen, T.J., Silbereis, J.C., Zhao, C., Baranzini, S.E., Bruce, C.C., Otero, J.J., Huang, E.J., Nusse, R., Franklin, R.J. and Rowitch, D.H. (2011) Axin2 as Regulatory and Therapeutic Target in Newborn Brain Injury and Remyelination. Nature Neuroscience, 14, 1009-1016. https://doi.org/10.1038/nn.2855

[14] O’Shea, T.M., Allred, E.N., Dammann, O., Hirtz, D., Kuban, K.C., Paneth, N. and Leviton, A. (2009) The ELGAN Study of the Brain and Related Disorders in Extremely Low Gestational Age Newborns. Early Human Development, 85, 719-725. https://doi.org/10.1016/j.earlhumdev.2009.08.060

[15] Juopperi, T.A., Schuler, W., Yuan, X., Collector, M.I., Dang, C.V. and Sharkis, S.J. (2007) Isolation of Bone Marrow-Derived Stem Cells Using Density-Gradient Separation. Experimental Hematology, 35, 335-341. https://doi.org/10.1016/j.exphem.2006.09.014

[16] Zhu, M., Heydarkhan-Hagvall, S., Hedrick, M., Benhaim, P. and Zuk, P. (2018) Manual Isolation of Adipose-Derived Stem Cells from Human Lipoaspirates. International Journal of Molecular Sciences, 19, 3475.

[17] Argentati, C., Morena, F., Bazzucchi, M., Armentano, I., Emiliani, C. and Martino, S. (2018) Adipose Stem Cell Translational Applications: From Bench-to-Bedside. International Journal of Molecular Sciences, 19, E3475.

[18] Palumbo, P., Lombardi, F., Siragusa, G., Cifone, M.G., Cinque, B. and Giuliani, M. (2018) Methods of Isolation, Characterization and Expansion of Human Adipose-Derived Stem Cells (ASCs): An Overview. International Journal of Molecular Sciences, 19, 1897. https://doi.org/10.3390/ijms19071897

[19] Jeong, Y.-M., Cheng, X.W., Lee, S., Lee, K.H., Cho, H., Kang, J.H. and Kim, W. (2017) Preconditioning with Far-Infrared Irradiation Enhances Proliferation, Cell Survival, and Migration of Rat Bone Marrow-Derived Stem Cells via CXCR4-ERK Pathways. Scientific Reports, 7, Article No. 13718. https://doi.org/10.1038/s41598-017-14219-w

[20] Giannelli, M., Chellini, F., Sassoli, C., Francini, F., Pini, A., Squecco, R., Nosi, D., Bani, D., Zecchi-Orlandini, S. and Formigli, L. (2012) Photoactivation of Bone Marrow Mesenchymal Stromal Cells with Diode Laser: Effects and Mechanisms of Action. Journal of Cellular Physiology, 228, 172-181. https://doi.org/10.1002/jcp.24119

[21] Palisano, R., Rosenbaum, P., Walter, S., Russell, D., Wood, E. and Galuppi, B. (1997) Development and Reliability of a System to Classify Gross Motor Function in Children with Cerebral Palsy. Developmental Medicine \& Child Neurology, 39, 214-223. https://doi.org/10.1111/j.1469-8749.1997.tb07414.x

[22] Palisano, R.J., Cameron, D., Rosenbaum, P.L., Walter, S.D. and Russell, D. (2006) Stability of the Gross Motor Function Classification System. Developmental Medicine \& Child Neurology, 48, 424-428. https://doi.org/10.1111/j.1469-8749.2006.tb01290.x

[23] Mezey, E., Key, S., Vogelsang, G., Szalayova, I., Lange, G.D. and Crain, B. (2003) Transplanted Bone Marrow Generates New Neurons in Human Brains. Proceedings of the National Academy of Sciences of the United States of America, 100, 1364-1369. https://doi.org/10.1073/pnas.0336479100

[24] Welte, K., Platzer, E., Lu, L., Gabrilove, J.L., Levi, E., Mertelsmann, R. and Moore, M.A. (1985) Purification and Biochemical Characterization of Human Pluripotent Hematopoietic Colony-Stimulating Factor. Proceedings of the National Academy of Sciences of the United States of America, 82, 1526-1530. 
https://doi.org/10.1073/pnas.82.5.1526

[25] Toth, Z.E., Leker, R.R., Shahar, T., Pastorino, S., Szalayova, I., Asemenew, B., Key, S., Parmelee, A., Mayer, B., Nemeth, K., Bratincsák, A. and Mezey, E. (2008) The Combination of Granulocyte Colony-Stimulating Factor and Stem Cell Factor Significantly Increases the Number of Bone Marrow-Derived Endothelial Cells in Brains of Mice Following Cerebral Ischemia. Blood, 111, 5544-5552.

https://doi.org/10.1182/blood-2007-10-119073

[26] Arien-Zakay, H., Lecht, S., Bercu, M.M., Tabakman, R., Kohen, R., Galski, H., Nagler, A. and Lazarovici, P. (2009) Neuroprotection by Cord Blood Neural Progenitors Involves Antioxidants, Neurotrophic and Angiogenic Factors. Experimental Neurology, 216, 83-94. https://doi.org/10.1016/j.expneurol.2008.11.006

[27] Andressen, C. (2013) Neural Stem Cells: From Neurobiology to Clinical Applications. Current Pharmaceutical Biotechnology, 14, 20-28. https://doi.org/10.2174/138920113804805412

[28] Purandare, C., Shitole, D.G., Belle, V., Kedari, A., Bora, N. and Joshi, M. (2012) Therapeutic Potential of Autologous Stem Cell Transplantation for Cerebral Palsy. Case Reports in Transplantation, 2012, Article ID: 825289. https://doi.org/10.1155/2012/825289

[29] Papadopoulos, K.I., Low, S.S., Aw, T.C. and Chantarojanasiri, T. (2011) Safety and Feasibility of Autologous Umbilical Cord Blood Transfusion in 2 Toddlers with Cerebral Palsy and the Role of Low Dose Granulocyte-Colony Stimulating Factor Injections. Restorative Neurology and Neuroscience, 29, 17-22.

https://doi.org/10.3233/RNN-2011-0572

[30] Wang, M., Yang, Y., Yang, D., Luo, F., Liang, W., Guo, S. and Xu, J. (2009) The Immunomodulatory Activity of Human Umbilical Cord Blood-Derived Mesenchymal Stem Cells in Vitro. Immunology, 126, 220-232. https://doi.org/10.1111/j.1365-2567.2008.02891.x

[31] Wang, L., Ji, H., Zhou, J., Xie, J., Zhong, Z., Li, M., Bai, W., Li, N., Zhang, Z., Wang, X., Zhu, D., Liu, Y. and Wu, M. (2013) Therapeutic Potential of Umbilical Cord Mesenchymal Stromal Cells Transplantation for Cerebral Palsy: A Case Report. Case Reports in Transplantation, 2013, Article ID: 146347. https://doi.org/10.1155/2013/146347

[32] Tigue, C.C., McKoy, J.M., Evens, A.M., Trifilio, S.M., Tallman, M.S. and Bennett, C.L. (2007) Granulocyte-Colony Stimulating Factor Administration to Healthy Individuals and Persons with Chronic Neutropenia or Cancer: An Overview of Safety Considerations from the Research on Adverse Drug Events and Reports Project. Bone Marrow Transplantation, 40, 185-192. https://doi.org/10.1038/sj.bmt.1705722

[33] Kuban, J.L., Hecht, A.B., Onderdonk, T. and Michael O’Shea, N. (2010) Understanding the Underlying Beneficial Biology of Stem Cells and the Development and Validation of More Relevant Animal Models Is Required. Pediatric Research, 67, 95-101. https://doi.org/10.1203/PDR.0b013e3181bf5fab

[34] Abi Chahine, N.H., Wehbe, T.W., Hilal, R.A., Zoghbi, V.V., Melki, A.E. and Bou Habib, E.B. (2016) Treatment of Cerebral Palsy with Stem Cells: A Report of 17 Cases. International Journal of Stem Cells, 9, 90-95. https://doi.org/10.15283/ijsc.2016.9.1.90

[35] Nguyen, L.T., Nguyen, A.T., Vu, C.D., Ngo, D.V. and Bui, A.V. (2017) Outcomes of Autologous Bone Marrow Mononuclear Cells for Cerebral Palsy: An Open Label Uncontrolled Clinical Trial. BMC Pediatrics, 17, 104. 
[36] Huang, L., Zhang, C., Gu, J., Wu, W., Shen, Z., Zhou, X. and Lu, H. (2018) A Randomized, Placebo-Controlled Trial of Human Umbilical Cord Blood Mesenchymal Stem Cell Infusion for Children with Cerebral Palsy. Cell Transplantation, 27, 325-334. https://doi.org/10.1177/0963689717729379

[37] Sharma, A., Gokulchandran, N., Chopra, G., Kulkarni, P., Lohia, M., Badhe, P. and Jacob, V.C. (2012) Administration of Autologous Bone Marrow-Derived Mononuclear Cells in Children with Incurable Neurological Disorders and Injury Is Safe and Improves Their Quality of Life. Cell Transplantation, 21, S79-S90. https://doi.org/10.3727/096368912X633798

[38] Shroff, G. and Das, L. (2014) Human Embryonic Stem Cell Therapy in Cerebral Palsy Children with Cortical Visual Impairment: A Case Series of 40 Patients. Journal of Cell Science \& Therapy, 5, 1-7.

[39] Ding, W., Bai, J., Zhang, J., Chen, Y., Cao, L., He, Y., Shen, L., Wang, F. and Tian, J. (2004) In Vivo Tracking of Implanted Stem Cells Using Radio-Labeled Transferrin Scintigraphy Panel. Nuclear Medicine and Biology, 31, 719-725.

[40] Sykova, E. and Jendelova, P. (2007) In Vivo Tracking of Stem Cells in Brain and Spinal Cord Injury. Progress in Brain Research, 161, 367-83.

https://doi.org/10.1016/S0079-6123(06)61026-1

[41] Ren, C., Yin, P., Ren, N., Wang, Z., Wang, J., Zhang, C., Ge, W., Geng, D. and Wang, X. (2018) Cerebrospinal Fluid-Stem Cell Interactions May Pave the Path for Cell-Based Therapy in Neurological Diseases. Stem Cell Research \& Therapy, 9, 66. https://doi.org/10.1186/s13287-018-0807-3

[42] Zakerinia, M., Kamgarpour, A., Nemati, H., Zare, H.R., Ghasemfar, M., Rezvani, A.R., Karimi, M., Nourani Khojasteh, H., Dehghani, M., Vojdani, R., Haghighat, S., Namdari, N., Rekabpoor, J., Tavazo, M., Amirghofran, S., Amirghofran, Z., Yosefipour, G.A. and Ramzi, M. (2018) Intrathecal Autologous Bone Marrow-Derived Hematopoietic Stem Cell Therapy in Neurological Diseases. International Journal of Organ Transplantation Medicine, 9, 157-167.

[43] Wang, X., Cheng, H., Hua, R., Yang, J., Dai, G., Zhang, Z., Wang, R., Qin, C. and An, Y. (2013) Effects of Bone Marrow Mesenchymal Stromal Cells on Gross Motor Function Measure Scores of Children with Cerebral Palsy: A Preliminary Clinical Study. Cytotherapy, 15, 1549-1562.

[44] Sun, J.M., Song, A.W., Case, L.E., Mikati, M.A., Gustafson, K.E., Simmons, R., Goldstein, R., Petry, J., McLaughlin, C., Waters-Pick, B., Chen, L.W., Wease, S., Blackwell, B., Worley, G., Troy, J. and Kurtzberg, J. (2017) Effect of Autologous Cord Blood Infusion on Motor Function and Brain Connectivity in Young Children with Cerebral Palsy: A Randomized, Placebo-Controlled Trial. STEM CELLS Translational Medicine, 6, 2071-2078. https://doi.org/10.1002/sctm.17-0102

[45] Jensen, A. (2014) Autologous Cord Blood Therapy for Infantile Cerebral Palsy: From Bench to Bedside. Obstetrics and Gynecology International, 2014, Article ID: 976321. https://doi.org/10.1155/2014/976321

[46] Meier, C., Middelanis, J., Wasielewski, B., Neuhoff, S., Roth-Haerer, A., Gantert, M., Dinse, H.R., Dermietzel, R. and Jensen, A. (2006) Spastic Paresis after Perinatal Brain Damage in Rats Is Reduced by Human Cord Blood Mononuclear Cells. Pediatric Research, 59, 244-249. https://doi.org/10.1203/01.pdr.0000197309.08852.f5

[47] Castillo-Melendez, M., Yawno, T., Jenkin, G. and Miller, S.L. (2013) Stem Cell Therapy to Protect and Repair the Developing Brain: A Review of Mechanisms of Action of Cord Blood and Amnion Epithelial Derived Cells. Frontiers in Neuroscience, 7, 194. https://doi.org/10.3389/fnins.2013.00194 
[48] Lee, Y.H., Choi, K.V., Moon, J.H., Jun, H.J., Kang, H.R., Oh, S.I., Kim, H.S., Um, J.S., Kim, M.J., Choi, Y.Y., Lee, Y.J., Kim, H.J., Lee, J.H., Son, S.M., Choi, S.J., Oh, W. and Yang, Y.S. (2012) Safety and Feasibility of Countering Neurological Impairment by Intravenous Administration of Autologous Cord Blood in Cerebral Palsy. Journal of Translational Medicine, 10, 58.

https://doi.org/10.1186/1479-5876-10-58

[49] Vrhovac, R., Peri, Z., Jurenec, S., Kardum-Skelin, I., Jelić-Puskarić, B. and Jaksic, B. (2010) Post-Thaw Viability of Cryopreserved Hematopoietic Progenitor Cell Grafts: Does It Matter? Collegium Antropologicum, 34, 163-169. 